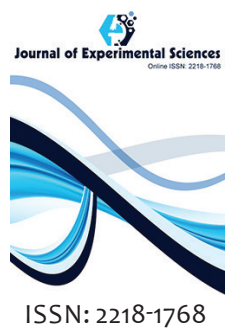

Received: March 13, 2018 Accepted: May 21, 2018 Published May 29, 2018

*Corresponding Author: Surya Narayan Pradhan Email: patrabiswajitogo@ gmail.com

\section{A study on socio-economic aspects of betel vine cultivation of Bhogarai area of Balasore District, Odisha}

\author{
Biswajit Patra, Surya Narayan Pradhan* \\ School of Life Sciences, Sambalpur University, Jyoti Vihar, Odisha 768 019, India
}

\begin{abstract}
Betel vine (Piper betle L.) (family: Piperaceae) is an economically important plant. There are 2 varieties are cultivated in Bhogarai area of Balasore District, Odisha. Leaves of Piper betle possess several bioactivities and are used in traditional medicinal systems. Production of crop is the result of interaction of the genetic characters and the environmental factors that govern the crop growth. The agro-biological factors limiting the production were severity of pests and diseases, inadequacy of water, soil condition, severity of rains and winds. Traditionally managed operations and untrained labour, poor planting materials are the main causes of low yield of betel leaf. The present paper also focused on problems in marketing, methods of cultivation, diseases of betel vine and their various symptoms and future prospects for preventions.
\end{abstract}

KEYWORDS: Betel vine, Bhogarai, cultivation, diseases, varieties

\section{INTODUCTION}

Medicinal plants play important role in human life. Most of these are wild in distribution and few are cultivated. Production of crop is the result of interaction of the genetic characters and the environmental factors that govern the crop growth. Varieties differ mostly in their genetic constitution besides physiological adaptability. Rainfall, temperature and soil constitute the most important environmental factors. Crop land or agro-ecosystem, one of the man-made ecosystems is very much dependent on external energy supply (irrigation, fertilizers etc.) on one hand and other inputs such as land preparation, weed and pest control, quality of seed or seedlings on the other [1]. Domestication of cultivated plants is an evolutionary process operating under the influence of human activities. With the origin of modern agriculture, new techniques of cultivation has been used bringing more plants into cultivation. In agricultural studies, more emphasis is given on production of economic return but in the study of plant ecology, production includes other non-economic parts such as straw, wastes and underground parts. The roots play an important role in supplying nutrients, after decomposing, to the subsequent crops in the soil. The activity of soil micro-organisms mostly influenced by the quality of underground parts left for decomposition. Productivity in crops is maintained by virtue of large energy inputs involving cultivation, irrigation, fertilizer application and genetic selection. The proper functioning of the crop fields depends mostly on the using of human labour as an important energy input [2]. The continuance of harvest of same crops in the same lands over the years resulted in loss of biogenic salts and soil nutrients such as sodium, phosphorous, potassium etc. In order to maintain the high rate of production, the loss of nutrients was compensated with additional supply of fertilizer. Leaves of Piper betle possess several bioactive components and are used in traditional medicinal systems [3,4]. Pan leaves used as a post meal mouth freshener [5]. Betel vine is a perennial dioecious plant. The leaves of pan are the economically important part [6]. Currently more than 200 cultivars are cultivated in several states of India for its leaves, which are used mainly for chewing purposes. The farmers and consumers name the cultivars after their localities, village or towns. The cultivers Bali and Chandrakana are cultivated in Bhogarai [7].

\section{STUDY AREA AND CLIMATE}

Balasore is one of the coastal district of Odisha. The soil of central region is mostly clay, clay loam and sandy loam which is fertile for paddy and betel vine cultivation. The field experiment was conducted in the field of Bhogarai area which is situated in Balasore district (Figure 1).

The coastal Odisha experiences maritime climate and receives the south-west monsoon rainfall. The temperature of the coastal area is moderate. The vegetation of coastal belt is influenced and determined largely by the estuaries and creeks formed by the rivers such as Bahuda, Rushikulya, Devi, Mahanadi, Kathajodi, Kuakhai, Brahmani, Baitarani, Budhabalanga, Panchupada, Subarnarekha and others.

Copyright: $\odot 2018$ The authors. This article is open access and licensed under the terms of the Creative Commons Attribution License (http://creativecommons.org/licenses/by/4.0/) which permits unrestricted, use, distribution and reproduction in any medium, or format for any purpose, even commercially provided the work is properly cited. Attribution - You must give appropriate credit, provide a link to the license, and indicate if changes were made. 


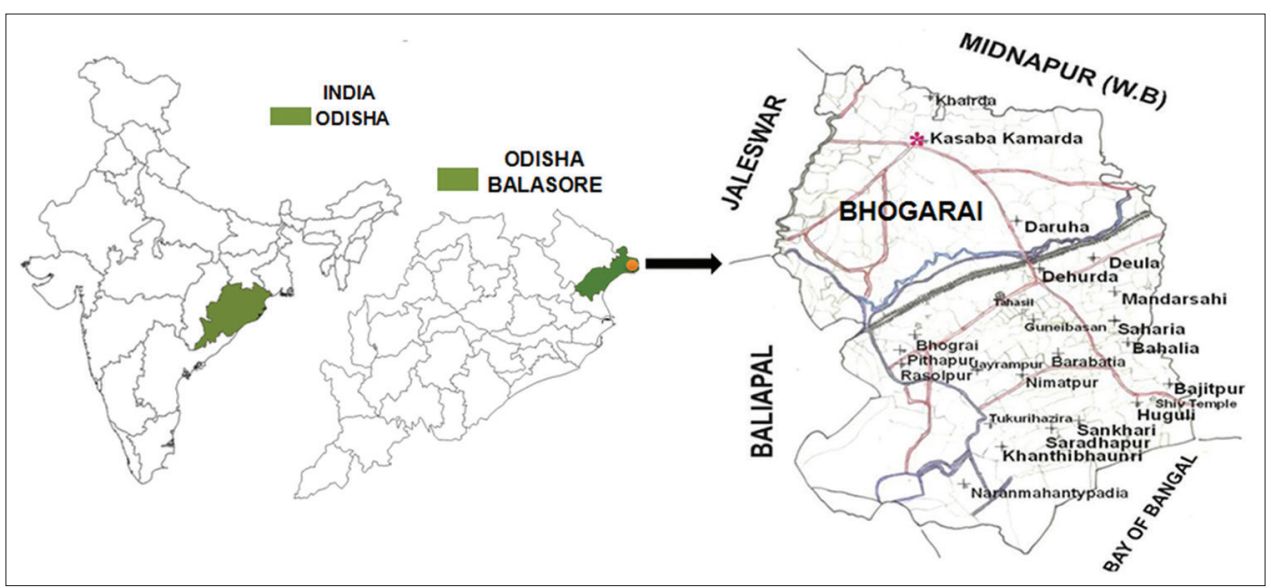

Figure 1: Map showing the study site of Bhogarai area of Balasore district, Odisha

The climate of the Balasore district is characterized by hot summer and high humidity during rainy season, dry winter and low diurnal range of temperature. The study area generally experiences three distinct seasons. Although the Bay of Bengal is very near to the study area (about $15 \mathrm{~km}$ ). The maximum and minimum temperatures recorded at Balasore Metrological Station during 2014-2015. During this period the minimum daily temperature $\left(14.2^{\circ} \mathrm{C}\right)$ was recorded in the month of January 2015. In summer season the minimum daily temperature ranged from $23.3^{\circ} \mathrm{C}$ to $27.1^{\circ} \mathrm{C}$, while in rainy season (July-October) minimum ranged from 24.1 to $25.5^{\circ} \mathrm{C}$ and in winter it ranged from 14.2 to $18.9^{\circ} \mathrm{C}$. The daily maximum temperature was recorded during the year was $36.7^{\circ} \mathrm{C}$ in the month of May 2015. During the summer season the daily maximum temperature ranged from $32.8^{\circ} \mathrm{C}$ to $36.7^{\circ} \mathrm{C}$. In winter the maximum temperature ranged from $24.9^{\circ} \mathrm{C}$ to $29.3^{\circ} \mathrm{C}$, while in rainy season it varied from 30.1 to $31.7^{\circ} \mathrm{C}$. The rainy season starts in the experimental area during the middle of June. The average annual rainfall of the area is $675.6 \mathrm{~mm}$. During the year 2014-15 the highest rainfall was recorded in the month of June 2015 i.e. $228.9 \mathrm{~mm}$ and lowest in the month of October $(2.0 \mathrm{~mm})$. Due to climate change very lowest rainfall was recorded in rainy season. It was observed that soil property in Bhogarai revenue area varies at different place. Two types of soil are seen in Bhogarai. i.e. sandy-loam and clay-loam. It was noticed that the production of Piper betle L. grows well in sandy-loam soil as compared to clay-loam soil.

\section{MATERIAL AND METHODS}

Different places of Bhogarai revenue area of Balasore district of Odisha, under study, were visited in different seasons during 2014-2015 to collect information about pan (Piper betle L.). During the collection of the specimens morphological forms along with ecological notes were documented. The diseases of the plant species were identified and reported, on the basis of plant specimen collected, personal observation and interviews (group, personal, electronic and telephonic) made during the study period. The rural areas were visited and discussion with farmers and labours was made and they were interviewed to collect information on cultivation, harvesting, processing, disease management, marketing, problems and current uses of the species. A questionnaire was developed to collected the required information. Fresh pan leaves collected were brought to laboratory in a polythin cover. The specimens were identified, described and illustrated with the help of Flora Book "The Botany of Bihar and Odisha” [8] and research articles [10,11,12]. The plants are enumerated with their correct scientific name, family name, local Odia name and English name along with the botanical descriptions of the species.

\section{RESULTS}

\section{The Pan Species}

The cultivated pan species belongs to the family Piperaceae. Biosystematists characterized the species as a dioecious, climbing shrub with woody root, stem stout with pinkish-strip along, node dilated and rooting $[8,9,10]$. The two varieties of Piper betle cultivated in the study area are characterized as follows. (1) Piper betle L. var. Jaleswar. In local vernacular it is known differently as Bali Pana, Desi Pana, Mitha Pana, Birkuli Pana. (Bali Pana - Leaves long, thin, smell good, juice and sweet taste) (2) Piper betle L. var. Bangladeshi. In local vernacular it is known differently as Chandrakana Pana, Matiali Pana, Athila Pana, Raga Pana. (Chandrakana Pana - Leaves rounded and big, thick, smell good, pungent taste and near the petiole surface are very close)

\section{Methods of Cultivation}

During the present study, it was observed that, vines are cultivated for harvesting the heart shaped green leaves. The cultivation of pan grows under an indigenous system of "environmental chamber". This covered structure is known as "Baraja". The Baraja structure is made up of locally available materials like bamboo stems (Bambusa bambos (L.) Voss.) and (Bambusa vulgaris Sch. ex Wendl.), paddy straw (Oryza sativa L.), jute (Corchorus capsularis L.), leaves of coconut (Cocos nucifera L.) and Khadi or Chaee stick (Arunda donox L.). Proper irrigation and fertile soil is necessary for betel vine. The farm yard is fenced with bamboo sticks and coconut leaves. The vine is a highly labour intensive crop. The suitable 
time for irrigation is morning or evening [13]. Betel vine is suitable for well drained clay loam and sandy loam soils [12].

Barajas are rectangular in shape and normal workable size is $40 \mathrm{~m}$ $\times 30 \mathrm{~m}$. Most of the Barajas are small, so that maintenance are easy and the cost of erection are within manageable limits. The Barajas are mainly preferred for high-land and the shape carries humidity and temperature control. To minimize the wind impact, thatching on outer side are thickest. So that, the wind velocity entered the Baraja has reduced. The south side has thinnest to allow some light from that direction. The top of the Baraja has covered by bamboo stems, Khadi or Chaee stick and coconut leaves in order to reduce the light incident on the plant and soil surface. Hight of the Baraja depended on the growth of the vine. Inside the Baraja cultivators have a good thinking of space management. The space inside the Baraja does not permit very wide inter-row spacing. Planting has done in double rows leaving just enough space for one person to move sideways. Free space on four sides and between two rows inside the Baraja was used for maintenance and movement of workers and labors for various operations.

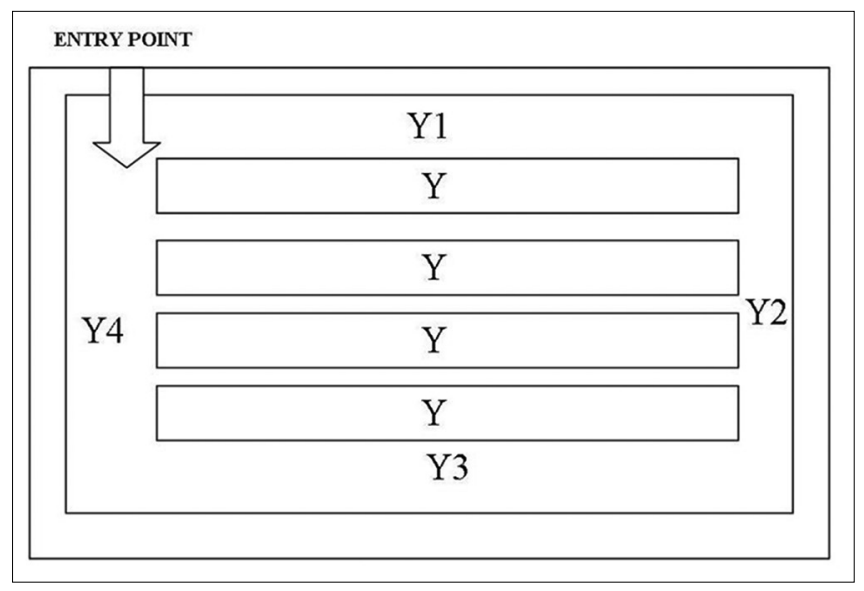

Where Y, Y1,Y2, Y3 \& Y4 are the free space inside the Baraja.

\section{Establishment of New Crop}

Piper betle L. is a vegetatively propagated crop. Cutting with one or two nodes along with attached leaves are generally used as the propagation material. Planting season varies from place to place. After plantation it takes about one month for root formation and sprouting. When 5-7 leaves are emerged, then plants are provided support.

\section{Harvesting Betel Leaf}

Harvesting starts after 1 year of plating by plucking the leaves. Local people term the harvests as, "Nua pan", "Jhanji pan","Jagannath pan", "Vejua pan”, "Maghei pan". Nua pan collects in mid of February-April. During this plucking time cultivators removes dry or damage leaves. Jhanji pan collects during May-mid July. This season provides highest yield. This time cultivators removes some damaged Khadi or Chaee stick. Jagannath pan collects during August-September. In this plucking farmers selectively collects the leaves from the lower part of the branches. Vejua pan collects during OctoberNovember. In this plucking cultivators selects the top portion of branches. Maghei pan harvests during December-January and continues till February. In this collection all total leaves are pluck. This time pan sizes are too small.

\section{Betel Leaf Processing}

Farmers uses cotton sheets or paddy straw and sprays water on leaves for keep fresh. Eighty pan leaves make a "Pono". Then leaves are sold in the local markets or transport to nearby cities [12].

\section{Disease Management}

Three diseases are seen in betel vine, namely "Foot rot", "Leaf spot", and "Powdery mildew" [14].

\section{Foot Rot}

The most important fungal disease caused by Phytophthora spp. [15]. Foot rot is harmful to the plantation [12]. Hector, 1927 observed a species of Phytophthora and later identified as P. nicotianae var. parasitica. Dastur, 1927 and Mahmud, 1949 in Madhya Pradesh, reported that the occurrence of foot rot caused by P. parasitica and Phythium vexans de Bery (Phythium piperinum Dastur) [12].

The description of the symptoms has been given by Dastur [12]. The lamina of leaves slowly start to droop, and petiole remains erect. This disease locally called 'Khada kala' or 'Khada pacha' or 'Madua'. To prevent these disease from spreading, local cultivators spraying Blitox and Tegron medicine.

\section{Leaf Spot}

Leaf spot disease caused by Fusarium semitectum Berk. et Rav. has been described by Chattopadhyay and Sen gupta [16]. This diseases also caused by Drechslera rostrata, Cladosporium pipericola, Cercospora piperis-betle and Corynespora cassicola were reported in Madhya Pradesh and Uttar Pradesh in India by Mohanty and Mohapatra, 1968; Singh and Shankar, 1971; Maiti and Sen $[17,18,19]$.

Leaf spot disease locally known as 'Champa fulia' or 'Champa tipa'. Tip of the leaves seen small and rolling. When noticed farmers cut diseased leaves immediately, otherwise within few days infection spread on main stem of betel vines. It also spread from one vine to another through ants and insects. This disease seen in rainy season. To prevent these disease by spraying Diethen-M 45 and urea water are used by the farmers [19].

\section{Powdery Mildew}

In India, Narasimhan, 1933 observed the disease to be occurring in Mysore. Powdery mildew disease mainly caused by Oidium piperis Uppal [20]. 
Table 1: Each seasonal and annual money investment in a Baraja $(40 \mathrm{~m} \times 30 \mathrm{~m}$ approximate $)$ during 2014-15

\begin{tabular}{|c|c|c|c|c|c|c|c|c|}
\hline \multirow[t]{3}{*}{ Activities } & \multicolumn{2}{|c|}{$\begin{array}{c}\text { No.of workers engaged } \\
\text { per day }\end{array}$} & \multicolumn{6}{|c|}{ Money investment (Rupees) } \\
\hline & \multirow[t]{2}{*}{ Male } & \multirow[t]{2}{*}{ Female } & \multicolumn{5}{|c|}{ Harvesting period } & \multirow[t]{2}{*}{ Yearly } \\
\hline & & & Feb-April & May-July & Aug-Sep & Oct-Nov & Dec-Jan & \\
\hline Ploughing & 1 & - & 1000 & 0 & 0 & 0 & 0 & 1000 \\
\hline Bed preparation & 2 & 1 & 600 & 0 & 0 & 0 & 0 & 600 \\
\hline Seedling charge & - & - & 500 & 0 & 0 & 0 & 0 & 500 \\
\hline Buy seedling & 1 & - & 200 & 0 & 0 & 0 & 0 & 200 \\
\hline seedling plantation & 3 & 2 & 1000 & 1000 & 1000 & 1000 & 0 & 4000 \\
\hline Irrigation \& watering & - & 1 & 9000 & 9000 & 6000 & 6000 & 6000 & 36000 \\
\hline Harvesting & 2 & - & 400 & 400 & 400 & 400 & 400 & 2000 \\
\hline Market shifting charge & 2 & - & 200 & 200 & 200 & 200 & 200 & 1000 \\
\hline Grand Total & & & 12900 & 10600 & 7600 & 7600 & 6600 & 45300 \\
\hline Total (Without watering) & & & 3900 & 1600 & 1600 & 1600 & 600 & 9300 \\
\hline
\end{tabular}

1 day labour charge $=$ Rs. $200.00 ; 1 / 2$ day labour charge $=$ Rs. $100.00 ; 1$ seedling charge $=$ Rs. $5.00 ;$ Number of seedlings buy from market $=100$;

1 plant $=25$ leaves; 100 plants $=2500$ leaves; 40 leaves $=1$ koda; 2500 leaves $=62.5$ koda

This disease locally known as 'Jhalma'. The disease appears on the under surface of the leaves as white to light brown powdery patches. In this stage small white and black dust found in upper and lower portion of the leaves. This is highly infectious. There are no prevention to cure this disease. Farmers spraying dry fruit dust and leaf juice of Neem tree (Azadirachta indica A. Juss.) mixed with water above the leaves of the betel vine.

\section{Problems of the cultivator}

Cultivation of betel vine is affected by many unknown diseases and insects that results in great loss for the farmers. Another problem is transportation of seedling. It occurs the damage of the seedlings. The problems in marketing were transport, too many middlemen, absence of grading, fluctuating price and inadequacy of finance. The agro-biological factors limiting the production were severity of pests and diseases, inadequacy of water, soil condition, severity of rains and winds. Traditionally managed operations and untrained labour, poor planting materials are the main causes of low yield of betel leaf.

\section{Marketing and socio-economic status}

Each seasonal and annual money investment in a Baraja of Bhogarai during the study period were considered. Table 1 represented that money invested for one year including irrigation and watering has Rs. 45300.00 in which irrigation and watering has Rs. 36000.00 only. But it has too expensive for a cultivator. So, some cultivators can't engaged labours and gave watering by own man power. Thus, they have relaxing from watering labour charges and the total money investment in a year have Rs. 9300.00 only. Hence, without irrigation and watering charges cultivator spent Rs. 3900.00, Rs. 1600.00, Rs. 1600.00, Rs. 1600.00 and Rs. 600.00 for each harvesting in a year respectively. If irrigation and watering charges included the spent shows Rs. 12900.00 , Rs. 10600.00, Rs. 7600.00 , Rs. 7600.00 and Rs. 6600.00 respectively.

Cultivators spent huge amount of money for their traditional cultivation so that they want good output from local market. But the area has famous for Piper betle cultivation and the
Table 2: Annual and seasonal income (Rupees) of a cultivator from local market during 2014-15

\begin{tabular}{lcccccc}
\hline $\begin{array}{l}\text { Source of } \\
\text { income }\end{array}$ & \multicolumn{4}{c}{ Harvesting period } & Yearly \\
\cline { 2 - 6 } & Feb-April & May-July & Aug-Sep & Oct-Nov & Dec-Jan & \\
\hline Local Market & 2500 & 1250 & 1875 & 1875 & 2500 & 10,000 \\
Middle man & 3125 & 1875 & 2500 & 2500 & 3125 & 13,125 \\
\hline
\end{tabular}

Table 3: Seasonal market price and seasonal income from one bundle (Koda) during 2014-15

\begin{tabular}{lcccc}
\hline Season & \multicolumn{2}{c}{$\begin{array}{c}\text { Price (Indian Rupees) in one } \\
\text { bundle (l koda) }\end{array}$} & \multicolumn{2}{c}{ Income from one bundle } \\
\cline { 2 - 5 } & Local market & Middle man & Local market & Middle man \\
\hline Winter & 40 & 50 & 2500 & 3125 \\
Rainy & 30 & 40 & 1875 & 2500 \\
Summer & 20 & 30 & 1250 & 1875 \\
Total & & & 5625 & 7500 \\
\hline
\end{tabular}

1 Koda $=40$ leaves

market price has very low. Hence, growers goes to the middle man for selling. Thus. There are two types of income source for cultivators. Yearly income of pan from local market found Rs. 10,000.00 where middle man gives Rs. 13,125.00. and income from local market per harvesting has Rs. 2500.00, Rs. 1250.00, Rs. 1875.00, Rs. 1875.00 and Rs. 2500.00 respectively. Through middle man growers get more profits so the incomes per harvesting has Rs. 3125.00 , Rs. 1875.00 , Rs. 2500.00 , Rs. 2500.00 and Rs. 3125.00 respectively (Table 2).

Seasonal market price changed with season on the basis of quality of pan. In winter season local market price was higher i.e. Rs. 2500.00, rainy season Rs. 1875.00 and in summer season price was Rs. 1250.00 i.e. lower in all season. Middle man price was also higher in winter season and lower in summer season. Hence, total income from one bundle from all three season has Rs. 7500.00 for middle man price and Rs. 5625.00 for local market price (Table 3).

Farmers working annually 360 days in a pan Baraja including 26 days other minor work inside the Baraja. Labours take 5 holidays in a year and these holidays are their own wishes. This 
Table 4: Number of working day and number of workers in a pan Baraja during 2014-15

\begin{tabular}{|c|c|c|c|c|c|c|c|c|}
\hline \multirow[t]{3}{*}{ Activities } & \multicolumn{2}{|c|}{$\begin{array}{c}\text { No.of workers engaged } \\
\text { per day }\end{array}$} & \multicolumn{6}{|c|}{ No. of working days } \\
\hline & \multirow[t]{2}{*}{ Male } & \multirow[t]{2}{*}{ Female } & \multicolumn{5}{|c|}{ Harvesting period } & \multirow[t]{2}{*}{ Yearly } \\
\hline & & & Feb-April & May-July & Aug-Sep & Oct-Nov & Dec-Jan & \\
\hline Ploughing & 1 & 0 & 5 & 1 & 1 & 1 & 1 & 9 \\
\hline Bed preparation & 2 & 1 & 1 & 0 & 0 & 0 & 0 & 1 \\
\hline Seedling charge & 0 & 0 & 0 & 0 & 0 & 0 & 0 & 0 \\
\hline Buy seedling & 1 & 0 & 1 & 0 & 0 & 0 & 0 & 1 \\
\hline seedling plantation & 3 & 2 & 1 & 1 & 1 & 1 & 1 & 5 \\
\hline Irrigation \& watering & 0 & 1 & 90 & 90 & 60 & 60 & 60 & 360 \\
\hline Harvesting & 2 & 0 & 1 & 1 & 1 & 1 & 1 & 5 \\
\hline Market shifting charge & 2 & 0 & 1 & 1 & 1 & 1 & 1 & 5 \\
\hline
\end{tabular}

5 days Durga puja holiday. As cultivators belief that goddess Kali and goddess Durga live inside the pan Baraja. So, shoes are strictly prohibited inside the Baraja

may be one day in continuing month or serial of days in one month (Table 4).

\section{Current Uses}

A betel quid is used as mouth freshener, leaves used for chewing. Leaves also used to maintain good oral hygiene, improves digestion, prevents carcinogenesis in the oral cavity, treats gastric ulcers, cures boils, relieves headache and also prevent bronchitis, constipation, congestion, coughs and asthma.

\section{DISCUSSION \& CONCLUSION}

A well coordination between farmers, traders, scientists, administrators and policy makers initiated to boost up the national economy through proper exploration of this leaves. The central and state government should jointly take necessary steps to improve pest management of betel farm activities and also establish a research and development board for awareness among betel growers. There also take steps to reduce intermediaries in marketing for stabilized the betel prices. There has also no research based information on the effect of soil erosion due to weeding and cleaning around the betel vines. Piper betle showed valuable antibacterial activities. Market price should be decided and published frequently by the government to help the farmers. Periodic inspection of the farm is required to prevent diseases. Establishing export promotion council through which betel leaves can be exported to every corner of India and outside India. It can only possible if opening more new market. Awareness of plant protection practices to control pests and diseases are required. If the government should take steps through NGOs and agencies to educate the farmers. Organized credit through commercial banks for the cultivation of betel vine would help the growers from depending on the credit from traders. To achieve good yield, selection of healthy plant materials are necessary. There are need to select good quality material through new planting techniques with modern technology. The efficiency of the system can be increased by periodic inspection of the farm which required to prevent the diseases.

\section{REFERENCES}

1. Pattanaik, P.K., 2002. Productivity, energitics and environmental cost analysis of sugarcane crop ecosystem. Ph.D. Thesis, Berhampur
University, Odisha, India. 12-22.

2. Nisanka, S. and Misra, M.K., 1990. Ecological study of an Indian Village Ecosystem. Biomass Production and Consumption. 23: 117-136.

3. Kumar, A., Garg, B.R., Rajput, G., Chandel, D., Muwaalia, A., Bala, I. \& Singh, S., 2010. Antibacterial activity and quantitative determination of protein from leaf of Datura stramonium and Piper betle plants. Pharmacophore. 1(3): 184-195.

4. Patra, B., Sahu, D. and Misra, M.K., 2014. Ethno-medicobotanical studies of Mohana area of Gajapati district, Odisha, India. International Journal of Herbal Medicine. 2(4): 40-45.

5. Sharma, M.L., Rawat, A.K.S., Khanna, R.K., Chowdhury, A.R. and Raina, R.M., 1996. Flavour characteristics of betel leaves. Euro cosmetics. 5: 22-24.

6. Chattopadhyay, S.B. \& Maity, S., 1967. Diseases of Bete/ vine and Spices. ICAR, New Delhi.

7. Balasubrahmanyam, V.R., Johri, J.K., Rawat, A.K.S., Tripathi, R.D. \& Chaurasia, R.S., 1995. Betel vine (Piper bet/e L.). NBRI Publication, Lucknow.

8. Haines, H.H., 1961. The Botany of Bihar and Odisha, London. Reprinted by B.S.I Howah, (1921-1925).

9. Chaveerach, A., Mokkamul, P., Sudmoon, R. \& Tanee, T., 2006. Ethnobotany of the genus Piper (Piperaceae) in Thailand. Ethnobotany Research \& Applications. 4: 223-231.

10. Agarwal, T., Singh, R., Shukla, A.D., Waris, I. \& Gujrati, A., 2012. Comparative analysis of antibacterial activity of four Piper betle varieties. Advances in Applied Science Research. 3(2): 698-705.

11. Dhongle, S.S. \& Kogje, K.K., 2013. Comparative Pharmacognostic study of leaves of two varieties of Piper betle L. namely calcutta Bangla and Assam kapoori. International Journal of Herbal Medicine. 1(3): 115-119.

12. Haider, M.R., Khair, A., Rahman, M.M. and Alam, M.K., 2013. Indigenous management practices of betel-leaf (Piper bet/e L.) cultivation by the Khasia community in Bangladesh. Indian Journal of Traditional Knowledge. Vol. 12(2), April, pp. 231-239.

13. Kaleeswari, V. and Sridhar, T., 2013. A study on Betel vine cultivation and market crisis in Karur district. Indian Journal of Applied Research. Vol. 3.

14. Vijayakumar, J. \& Arumugam, S., 2014. Odium piperis fungus identification for Piper betel plants using digital image processing. Journal of Theoretical and Applied Information Technology. 60 (2): 423-427.

15. Chattopadhyay, S.B. \& Maiti, S., 1990. Diseases of Bete/ vine and spices. ICAR, New Delhi. 1-32.

16. Chattopadhyay, S.B. \& Sengupta, S.K., 1955. A new disease of Piper betle in West Bengal. Indian Phytopath. 8: 105-11.

17. Mohanty, N.M. \& Mahapatra, P.K., 1968. A new leaf spot disease of betel vine caused by Corynespora cassicola. Indian Phytopath. 21: $275-80$

18. Singh, R.A. \& Shanker, G., 1971. Some parasitic fungy in Piper bet/e L. in Varanasi, Utter Pradesh. Mycopath. Mycol. App/. 43: 109-15.

19. Maiti, S. \& Sen, C., 1979. Fungal diseases of betelvine. Pans. 25(2): 150-157.

20. Narasimhan, K.J., 1933. Annual report of mycology section of the year 1931-32. Adm. Rep. Dep. Agric. Mysore. 1931-32. Pp. 32-35. 